\title{
Öğrencilerin 'Etkileşimli İngilizce Dil Sınıfı' projesinden memnuniyetleri ve projenin öğrencilerin derse İngilizce katılım isteklilikleri üzerine etkileri
}

Ali KARAKAŞı

\begin{abstract}
APA: Karakaş, A. (2019). Öğrencilerin 'Etkileşimli İngilizce Dil Sınıfi' projesinden memnuniyetleri ve projenin öğrencilerin derse İngilizce katılım isteklilikleri üzerine etkileri. RumeliDE Dil ve Edebiyat Araşturmaları Dergisi, (16), 194-213. DOI: 10.29000/rumelide.618161
\end{abstract}

\section{$\ddot{O} \mathbf{z}$}

\begin{abstract}
İngilizce’nin dünyada artan önemine paralel olarak ülkemizde de İngilizce öğretimine ciddi anlamda önem verilmiş ve öğretim kalitesini arttırmak için ülkemizdeki her bir eğitim reformunda İngilizce öğretimi ile ilgili ciddi adımlar atılmıştır. Buna rağmen, ülkemizde İngilizce öğretimi halen istenilen seviyelere gelememiştir. Bunun en temel nedenlerinden biri, öğrencilerin İngilizce’ye karşı olumsuz tutumları ve gerçek amaçlı dil kullanım yoksunluğundan kaynaklanan ‘Íngilizce ne işime yarayacak’ kaygısıdır. Bu araştırmada, bu sorunlar göz önünde bulundurularak Burdur ìl Milli Eğitim Müdürlüğü ve Burdur Mehmet Akif Ersoy Üniversitesi Eğitim Fakültesi işbirliği ile yürütülen Etkileşimli İngilizce Dil Sınıfı projesi kapsamında Türk öğrencilerin yabancı öğrenciler eşliğinde ders işlemelerinin derse İngilizce katılım istekliliklerinde olumlu bir değişikliğe neden olup olmadığı, yabancı öğrencilerle ders işlemekten memnun olup olmadıkları ve proje ile ilgili genel görüşleri araştırılmıştır. Bu kapsamda, araştırmada 63 öğrenci yer almıştır ve veriler hem nicel hem de nitel veri toplama araçları ile toplanmıştır. Nicel verilerin analizi, öğrencilerin yabancı öğrenciler eşliğinde ders işlemelerinin derse İngilizce katılım istekliliklerini olumlu olarak arttırdığını ve öğrencilerin birçok açıdan yabancı öğrenciler ile ders işlemekten memnun olduklarını göstermiştir. Nitel veriler de nicel verileri doğrulayarak, öğrencilerin yabancı öğrenciler eşliğinde işledikleri dersleri zevkli ve eğlenceli bulduklarını, dil becerilerinin geliştiğini hissettiklerini ve projenin ilerleyen dönemlerde de devam etmesini arzuladıklarını ortaya çıkarmıştır. Kısacası, projenin öğrencilerin dile ve dil kullanımına ilişkin olumlu tutumlar geliştirmesine olanak sağladığı söylenebilir. Araştırma sonuçlarına dayanılarak, benzeri bağlamlarda uygulamaya yönelik neler yapılabileceği konusunda çeşitli önerilerde bulunulmuştur.
\end{abstract}

Anahtar kelimeler: Etkileşimli İngilizce dil sınıfı, İngilizce iletişim istekliliği, yabancı öğrenciler.

\section{Students' satisfaction with the 'Interactive English Language Classes' project and the effects of the project on students' willingness to communicate in classes}

\begin{abstract}
In parallel with the increasing prominence of English in the world, considerable importance has been attached to the teaching of English in our country and serious steps have been taken in every education reform to improve the quality of language teaching. Despite all efforts, English language teaching in our country has not reached the desired levels. One of the main reasons for this is the students' negative attitudes towards English and the concern of 'what good would English do to me', which originates from the dearth of real-life language use. Considering these problems, this research seeks to explore whether the accompaniment of Turkish students by foreign students in English
\end{abstract}

1 Dr. Öğr. Üyesi, Burdur Mehmet Akif Ersoy Üniversitesi, Eğitim Fakültesi, Yabancı Diller Eğitimi Bölümü, İngiliz Dili Eğitimi ABD (Burdur, Türkiye), akarakas@mehmetakif.edu.tr, ORCID ID: oooo-0002-9790-8562 [Makale kayıt tarihi: 25.06.2019-kabul tarihi: 20.09.2019; DOI: 10.29000/rumelide.618161] 


\begin{abstract}
classes within the scope of the interactive English Language Class project carried out in cooperation with Burdur Provincial Directorate of National Education and Burdur Mehmet Akif Ersoy University Faculty of Education results in a positive change in their willingness to participate in classes, whether they are satisfied with the process of having their classes together with foreign students and what opinions they hold about the project in general. To this end, 63 students participated in the study and the data were collected with both quantitative and qualitative data collection tools. The analysis of the quantitative data showed that having classes with foreign students positively contributed to the students' willingness to participate in classes and that the students were pleased to study English with foreign students in many respects. Confirming the quantitative data, the analysis of qualitative data revealed that the students found the classes they had with foreign students enjoyable and fun, felt that their language skills had improved, and wished that the project would continue in the future. In short, the project may be said to have enabled students to develop positive attitudes towards language and language use. Drawing on the results, various suggestions have been made as to what can be further done in similar contexts from a practical dimension.
\end{abstract}

Keywords: Interactive English classes, willingness to communicate in English, foreign students.

\title{
Giriş
}

İngilizce'nin ortak bir dil olduğu dünyada bu dili konuşmak neredeyse bir gereklilik haline gelmiştir. Türkiye de İngilizce konuşmaya ve İngilizce konuşmanın temelinin atıldığı İngilizce derslerine önem veren ülkeler arasındadır (Büyükkantarcıoğlu, 2004; Doğançay-Aktuna, 1998). Ancak ülkemizdeki okullarda dilbilgisi ağırlıklı eğitim göz önünde bulundurulduğunda ve yabancı dil edinimi için, bu dilin kullanımının önemli olduğu düşünüldüğünde; dil edinimi için gerekli olan belli şartların sağlanmadığı görülebilir. Dolayısıyla derslerde hedef dilin kullanımının sağlanması gereklidir. Bu konuyla ilgili olarak, Şener (2014) öğrencilerin hedef dili öğrenmeleri için bu dilin kullanılmasının gerekliliğini, aynı zamanda İngilizce iletişim kurma isteğinin hem hedef dili öğrenmeyi hem de bu dili kullanmayı kolaylaştırdığını vurgulamaktadır. Çelebi’nin (2006) belirttiği gibi

Teknolojik gelişmenin, değișmenin kültürel değișimin daha ilerisinde olduğu 21. yüzyılda yabancı dil bilmenin, öğrenmenin önemi tartışlamaz. Çağın teknolojisini, bilimini öğrenmek, anlamak, sahiplenmek ve üretmek zorunda olan, Avrupa Birliği üyesi olma hedefinde ve yolundaki Türkiye'de bu durum diğer ülkelerden daha da ciddiyetle ele alınması gereken bir konudur. Artık bir yabancı dilin yeterli olmadığı günümüzde, entelektüel bir meslekleşmeye doğru gidildiği görülmekte olup, bilgisayar ve yabancı dil bilmek çağa yetişmek, onu yakalayabilmek için olmazsa olmaz bir koşuttur (s. 286).

Başka bir ifade ile "[g]ünümüzde İngilizce bilmek, bilgisayar kullanmak kadar temel bir gereklilik haline gelmiştir” (Koru ve Akesson, 2011, s. 2). 21. yüzyllda en az bir yabancı dil bilmenin önemi tartışlamayacak kadar büyüktür. Günümüzde çağın bireyleri için artık tek bir yabancı dil bilgisi yeterli olarak görülmemektedir. Bilgisayar ve teknoloji çağı olarak adlandırılan içinde bulunduğumuz dönemde dil ve teknoloji okuryazarlığı bir meslekí hedef olmaktan çıkıp her meslekten insanın sahip olması gereken temel bir özellik haline gelmiştir. Bu konuyla ilgili olarak, Doğan (1996) 21. yüzyıl insanının sahip olması gereken özellikleri aşağıdaki gibi sıralamıştır:

1. Çağa uygun eğitim görmüş olmak,

2. Geçerli bir mesleğe sahip olmak,

3. Sorunların çözümünü araştırmada arayan bir karakter geliştirmek,

4. Toplumsal ilişkilerde gerekli entelektüel ve duygusal derinliğe ulaşmış olmak, 
Students' satisfaction with the 'Interactive English Language Classes' project and the effects of the project on students' willingness to communicate in classes / A. Karakaş (p. 194-213)

5. Anadili dışında geçerli bir yabancı dili iyi bilmek (s. 100).

Yukarıdaki ifadelerden de anlaşlacağı üzere, bilgisayar çağı insanın temel özelliklerinden birisi de yabancı dil bilgisidir. Hatta bazı araştırmacılara göre, yabancı dilbilgisi kriterlerin sağlanmasında yabancı dil bilen bireyleri yabancı dil bilmeyen bireylere göre daha avantajlı konuma getirmektedir. İnsani boyutun dışında, yabancı dil öğretiminin ve öğrenimin bir de bilimsel yönü bulunmaktadır. Yabancı dil öğretimini ve öğrenimini savunanların bilimsel gerekçelerini şöyle sıralamak mümkündür (Sarıhan, 2008).

1. Yabancı dil bilgisi turizmi geliştirir.

2. Yabancı dil bilgisi kalkınmayı hızlandırır.

3. Türkçe, bilim dili değildir.

4. Batı dilleri, özellikle İngilizce, uluslararası bir dil haline gelmiştir.

Kuşkusuz ki yukarıda bahsedilen nedenlerden dolayı yabancı dil bilmek, daha da açı söylemek gerekirse, İngilizce bilmek, bir lüks olmaktan çıkmış zaruret haline gelmiştir. Ülkemizde 20. yüzylın ortalarından itibaren dil öğretiminde pek çok yöntem uygulanmıştır. Ancak yapılan tüm çalışmalar ve uygulanan farklı yöntemlere rağmen ülkemizde halen İngilizce öğretiminin istenilen düzeyde olmadığı bir gerçektir. Bu durum British Council ve Tepav Proje Ekibi (2013) işbirliğinde Türkiye'deki devlet okullarında İngilizcenin öğrenimi ve öğretimine yönelik yürütülen kapsamlı bir araştırmada "öğrencilerin İngilizce olarak iletişim kurmayı ve dile işlevsellik kazandırmayı öğrenemedikleri” şeklinde dile getirilmiştir (s. 16). Benzer şekilde, bu durumun yükseköğretimdeki yansımaları şu şekilde ifade edilmiştir: “Türkiye'nin ‘İngilizce açığı’ yükseköğretim kalitesini olumsuz etkileyen ve akademik kaynaklara erişimi, uluslararası araştırma yayınlarını ve hem personelin, hem de öğrencilerin hareketliliğini kısıtlayan başlıca unsurlardandır" (British Council ve Tepav Proje Ekibi, 2015, s. 14). Türk insanın İngilizce'deki yetersizliği dünyaca ünlü Education First adlı uluslararası eğitim kuruluşunun İngilizce Yeterlik Endeks'i (English Proficiency Index) tarafindan da tescillenmiştir. Türkiye bu endekste 88 ülke arasında 73. sırada 'çok düşük dil seviyesi' (very low proficiency) kategorisinde yer almaktadır (“EF English Proficiency Index”, 2019). Türkiye’nin geride bıraktı̆̆ı ülkeler ise üçüncü dünya ülkeleri diyebileceğimiz Cezayir, Kamboçya, Afganistan ve Myanmar gibi ülkelerdir. Avrupa sıralamasında ise 27 ülke arasından sadece Azerbaycan’ı geride bırakarak 26. sırada yer almaktadır.

Mevcut durumdan haberdar olan yetkililer dil öğretiminde gerek bakanlık düzeyinde gerekse özel kurs ve okullar düzeyinde 'yabancı dili sınıfta nasıl daha etkin öğretiriz' sorusuyla oldukça meşgul olmuşlardır. Bu nedenle ülkemizdeki her bir eğitim reformunda İngilizce öğretim programına ayrı bir önem verilmiş ve mevcut duruma çareler aranmıştır. Temel değişimlerden biri, okul müfredatlarında İngilizce derslerinin çocuklara daha erken yaşta verilmesi olmuştur (Bayyurt, 2012; Haznedar, 2010). Doksanlı yılların ortalarına kadar altıncı sınıfta verilmeye başlanan İngilizce dersleri 1997 ve 2013 yılları arasında dördüncü sınıfta verilmiş ve en son $4+4+4$ olarak adlandırılan eğitim sistemi ile birlikte İngilizce dersleri ilkokul ikinci sınıftan itibaren verilmeye başlanmış ve İngilizce öğretiminde ayrık yaklaşımdan bütüncül (holistic) yaklaşıma ve soyut dilbilgisi temelli yaklaşımdan iletişimsel yaklaşıma bir geçiş olmuştur (Arıkan, 2017; Bayyurt, 2012; Gürsoy, Korkmaz ve Damar, 2013; Haznedar, 2010; Kırkgöz, 2009). Erken yaşın önemine ilişkin olarak, Prof. Yasemin Bayyurt Hürriyet Eğitime verdiği röportajda "Yabancı dil eğitiminde en kazançlı dönem[in] 2-7 yaş arası" olduğunu belirtmiş, bunun nedenini de şu şekilde açıklamıştır: "Bu süreçte çocuklar dil öğrenme gelişimini tamamlar ve sembollerle düşünmeye başlar” (Hürriyet Eğitim Eki, 2014). Anlaşllacağı üzere Prof. Bayyurt Milli Ĕ̆itim Bakanlığının (MEB) uygulamasının da ötesinde dil öğretiminin okul öncesi dönemde başlaması 
gerektiğini dolaylı olarak vurgulamıştır. Ayrıca, en son 2018 yılında revize edilen İngilizce dersi (İlkokul ve Ortaokul 2-8 sınıflar) programında dilin uluslararası alandaki iletişim işlevine özel bir vurgu yapılmış ve Hymes (1972) ve Widdowson (1978) gibi iletişimsel dil öğretimi yaklaşımının savunucularının fikirlerine oldukça önem atfedilmiştir. Bu bağlamda, programın genel amaçları arasında en belirgin olanı, dil öğretiminde öğrencilere 'iletişimsel yetiyi’ kazandırmak ve onları günlük etkileşimlerde gerçek amaçlı dil kullanımı ile dili işlevsel kullanarak öğretmek olmuştur (MEB, 2018).

Türkiye'de İngilizce öğretimini elen alan başka bir çalışmada, Yaman (2018) eğitim programlarındaki güncel ve yenilikçi değişiklikleri ve bununla beraber teknolojinin sınıf ortamlarında aktif kullanımını, ders materyal çeşitliliğini, okullarda dil etkileşimini arttıran projelerin artmasını İngilizce öğretiminde kayda değer firsatlar olarak ifade etmektedir. Aynı zamanda, İngilizce öğretiminde karşılaşılan zorluklardan bahsederken, İngilizce öğrenimine karşı isteksizlik ve önyargıların da İngilizce öğretim sürecindeki olumsuz etkisini dile getirmiştir. Aslına bakılırsa, alanyazındaki İngilizce iletişim istekliliği üzerine yapılan birçok çalışmada da buna benzer sonuçlar ortaya çıkmıştır. Örneğin, üniversite düzeyinde yürütülen çalışmalarda öğrencilerin İngilizce'ye karşı tutumunu ve sınıf içinde iletişim istekliliğini, yani dil kullanım arzusunu, öğretmenin öğrenciye olan tutumu, öğrencinin karakteri ve ruh hali, sınıf içindeki diğer öğrencilerin derse ve konuşmaya olan ilgisizlikleri, sınıfın atmosferi, dersin konusu, derste kullanılan materyaller, dersteki aktiviteler, öğretmen ve sınıf değişimi, öğrencilerin sınav olma biçimleri, öğrencinin motivasyonu, dilsel özgüveni, uluslararası topluma karşı olan tavrı, okudukları bölüm ve okudukları üniversitede İngilizce konuşan bireylerle doğrudan konuşma gibi faktörlerin önemli ölçüde etkilediği gözlenmiştir (bknz. Aydın, 2017; Hişmanoğlu ve Özüdoğru, 2017; Şener, 2014).

İngilizce öğretim programlarında yapılan reformlar dışında, çeşitli görsel ve yazılı medyada yer alana haberlere göre, MEB 2011 yılında 'Yabancı Dil Öğretiminin Geliştirilmesi Projesi'ni oluşturmak istemiş ve proje kapsamında dört yıllık süreçte yurtdışından ana dili İngilizce olan ülkelerden (İngiltere, Amerika, Kanada, Avustralya gibi) yaklaşık 40 bin öğretmeni istihdam etmeyi amaçlamış ve bunların Türk öğretmenlerle derslere gireceklerini, okullarda çeşitli alanlarda 'English Cafe'ler açllacağını ve bu alanlarda öğrencilere pratik yapma firsatı sunacaklarını belirtmiştir ("40 bin yabancı öğretmen", 2019). Temel amacı, İngilizce'nin daha iyi öğretilmesi ve konuşulması olan proje, muhtemelen 1.5 milyar TL'ye mal olacak bütçesinden dolayı uygulamaya konmamasına rağmen birçok kesimde, özellikle de İngilizce öğretmen adayları ve mezun olup atanamamış öğretmenler tarafından, büyük bir tepki ile karşlanmıştır (Coşkun, 2013). Proje aslında yeni öğretim programı ile uyumlu olarak iletişimsel dil öğretimi yaklaşımını hayata geçirmeye yönelik bir adım olarak düşünülebilir. Bu konuda zamanın MEB Projeler Koordinasyon Merkezi Başkanı Ünal Akyüz projenin hedefleri ile ilgili olarak şunları söylemiştir:

\footnotetext{
Yeni sistem konuşma ve derdini anlatabilme ağırlıklı. Türkiye'de yabancı dil öğrenimi konusunda bir kırılma noktası var. Biz bunun aşılmasını hedefliyoruz. İngilizce'nin dil bilgisi öğretiminden ibaret olmadığını, konuşma, yazma ve anlatmanın da önemli olduğu anlayışını getirmeyi hedefliyoruz (“İngilizce eğitime 40 bin öğretmen”, 2011, para. 8).
}

Günümüz şartlarında, dil öğreniminde asıl amaç, dersten geçer bir not alarak diploma alınması veya bir dil kursundan sertifika alınması olmaktan çıkarılıp; yabancı dili anlayabilme, konuşabilme ve yazabilme olmalıdır. Bireyin bunu başarabilmesinin en kolay yolu olarak araştırmalar ortaya koymaktadır ki; dilin konuşulduğu ortamda, orada kullanıldığı şekli ile öğrenmektir. Dil öğretiminde her öğrencinin ise yabancı dilin konuşulduğu ülkeye gitme ya da kendi ülkesinde yabancı dil konuşulan ortamlarda bulunma gibi bir imkânı olmamaktadır. Buradan hareketle, aşă̆ıda detaylarını sunacağımız projemiz ile küçük bir ilimizin okullarında yabancı dil eğitimi verilen sınıf ortamlarımızın 'Etkileşimli İngilizce 
Students' satisfaction with the 'Interactive English Language Classes' project and the effects of the project on students' willingness to communicate in classes / A. Karakaş (p. 194-213)

Dil Sınıfı' olarak düzenlenmesi, Burdur Mehmet Akif Ersoy Üniversitesi (MAKÜ) Eğitim Fakültesi’nde öğrenim görmek üzere yurt dışından gelen öğrencilerin yabancı dil derslerine katılarak, öğretimi yapılan yabancı dili konuşan ve kendi ana dillerinin kültürünü yaşayan kişiler aracılığı ile düzenlenecek faaliyetlerle öğrencilerde daha kalıcı ve daha yüksek düzeyde dil öğrenimini gerçekleştirmek amaçlanmıştır.

Bu süreçteki temel amaç ise öğrencilerin İngilizce’ye ve İngilizce öğrenimine yönelik tutumlarını olumlu yönde geliştirmek ve İngilizce’nin zorunlu bir ders olması dışında kendilerine kültürel ve iletişimsel anlamda ne gibi faydalarının olabileceğini ilk elden yabancı öğrenciler aracılığıyla ile yaşatmaktır. Burdur MAKÜ Eğitim Fakültesine yurt dışından gelen, proje kurum irtibat kişisi olan araştırmacı tarafindan seçilen öğrenciler aracıllğ̆ ile ilkokul ve ortaokul öğrencilerinde, İngilizce'nin telaffuz ve kullanımına yönelik farkındalık yaratılarak, öğrencilerimiz İngilizce'yi konuşma dili olarak kullanma konusunda cesaretlendirilmiştir. Bir anlamda, bu proje, MEB'in 2011'de hayata geçirmeye çalıştı̆̆ ülke çapındaki projeyi küçük çaplı ve düşük maliyetli olarak bölgedeki üniversitenin imkânlarından faydalanarak hayata geçirmeye çalışmış ve MEB'in hedefi olan dilin etkileşimli olarak iletişimsel amaçlarla kullanımını gerçekleştirmek istemiştir.

'Etkileşimli İngilizce Dil Sınıf' projesinin amacı, ilkokul ve ortaokullarda İngilizce dil eğitiminin ana dili Türkçe olmayan eğitim fakültesi öğrencilerinin okullardaki İngilizce öğretmenlerinin gözetimi altında haftada bir ya da iki ders saati boyunca derslere katılımları sağlanarak; okul öğrencilerinin konuşma becerilerinin verimliliğini artırmak, yaratıcı ve yenilikçi projelerin ortaya çımasını sağlanmak, sosyal girişimcilik ve projeler alanında öğretmenlerin ve dolaylı yoldan çocuk ve gençlerin kapasitelerini geliştirmektir. MAKÜ Eğitim Fakültesine yurt dışından gelen dekanlık tarafından seçilecek öğrenciler ile ilkokul ve ortaokul öğrencilerinin iletişimleriyle yabancı öğrenciler toplumumuza sosyal anlamda daha kolay ve hızlı entegre olmalarına yardımcı olmak; karşılıklı kültürel etkileşim ve hoşgörüyü artırmak amaçlanmaktadır. Şu an itibariyle tamamlanmış olan proje çeşitli aşamalardan oluşmaktadır. Projenin ilk aşaması pilot uygulama çalışmasından oluşmaktadır. Bu aşamada, Burdur ilinde bir pilot ortaokul seçilmiş ve MAKÜ Eğitim Fakültesinde öğrenim gören yabancı öğrenciler ortaokuldaki İngilizce öğretmeni eşliğinde sekiz hafta boyunca derslere katılmışlardır. Projenin ikinci aşaması ise yaygınlaştırma aşamasıdır. Bu aşamada, proje Burdur ilinde yer alan iki ilkokul, beş ortaokul ve bir lisede uygulanmaya başlamıştır. Proje, 2018-2019 Eğitim Öğretim yılının sonunda projede yer alan İngilizce öğretmenleri ve öğrencilere kapanış töreninde katılım belgelerinin verilmesiyle sona ermiştir. Aynı zamanda proje ve kapanış töreni yerel ve ulusal medyada da ilgi odağı olmuştur (bknz. Ek 1).

$\mathrm{Bu}$ çalışmanın amacı ise, 'Etkileşimli İngilizce Dil Sınıfı' projesinin pilot uygulamasında yer alan ortaokul öğrencileri ile yürütülen çalışmaların sonuçlarını paylaşmaktır. Bu amaç doğrultusunda, çalışmamız aşağıdaki üç araştırma sorusuna cevap aramaktadır.

1. Etkileşimli İngilizce dil sınıf projesi projesinde yer alan ortaokul öğrencilerinin yabancı öğrenciler eşliğinde ders işlemesinin, derslere İngilizce katılım istekliliklerinde (dili kullanma arzularında) olumlu ve anlamlı bir etkisi olmuş mudur?

2. Proje kapsamında yabancı öğrencilerle derslerini işleyen öğrenciler bu durumdan ne derece memnuniyet duymaktadır?

3. Projede yer alan ortaokul öğrencilerinin yabancı öğrencilerle ders işlemeyi içeren projeye ilişkin görüşleri nelerdir? 


\section{Yöntem}

\section{Araștırmanın deseni}

$\mathrm{Bu}$ araştırmada, Etkileşimli İngilizce dil sınıf projesinde yer alan ortaokul öğrencilerinin yabancı öğrenciler eşliğinde ders işlemelerinin derslere İngilizce katılım istekliliğinin olumlu olarak artıp artmadığı ve öğrencilerin bu projede yer almaktan duydukları memnuniyet ya da memnuniyetsizlik ve proje ile görüşleri açıklayıcı karma yöntem ile incelenmiştir (Creswell, 2008). Açılklayıcı karma yöntem kapsamında, araştırmacı önce nicel verileri toplamış daha sonra ise nicel verilere açıklık getirmek amacıyla nitel verileri toplamıştır. Nicel verilerin toplanmasında grup içi deneysel araştırma modeli ve tarama modeli kullanılmıştır. Grup içi deneysel araştırma modelinde araştırmacı tek bir gruba ön-test ve son-test, yani öğrencilerin derslere İngilizce katılım ölçeğini, uygulayıp aradaki müdahalenin (yabancı öğrencilerle ders işlemenin) iletişim istekliliği üzerindeki etkisini incelemiştir (Akbay, 2019; Allen, 2017).

\section{Araştırma örneklemi}

Araştırmanın örneklemini Burdur merkezde bir ortaokulda öğrenim gören 63 öğrenci oluşturmuştur. Öğrenciler proje pilot okulunda öğrenim gördüklerinden dolayı örneklem kolay ulaşılabilir ve ilgili uygulamaların kolay yapılabileceği birimlerden seçilmiştir. Bu açıdan örnekleme uygun örnekleme yöntemiyle seçilmiş ve araştırma amacına uygun kişiler araştırma örneklemine dâhil edilmiştir (Howitt ve Cramer, 2014). Bu 63 öğrenci memnuniyet anketine katılmış ama grup içi deneysel araştırmada ise ön-test ve/veya son-teste katılım göstermeyen dokuz öğrencinin örneklem dışı kalması sonucu deneysel çalışmada öğrencilerden sadece 54’ü yer almıştır. Nitel çalışmada ise sadece 15 öğrenci yer almıştır. Aşağıdaki tabloda araştırmaya katılan ortaokul öğrencilerinin yer aldıkları çalışma türlerine göre betimsel istatistikleri yer almaktadır.

Tablo 1. Araştırmaya katılan öğrencilerin demografik bilgileri

\begin{tabular}{|l|l|l|l|l|l|l|l|l|}
\hline Memnuniyet anketi & & & $\begin{array}{l}\text { İngilizce iletişim } \\
\text { İstekliliği Ölçeği }\end{array}$ & & $\begin{array}{l}\text { Nitel çalışma } \\
\text { (mülakat) }\end{array}$ & \\
\hline Cinsiyet & $\mathbf{n}$ & $\mathbf{\%}$ & Cinsiyet & $\mathbf{n}$ & $\mathbf{\%}$ & Cinsiyet & $\mathbf{n}$ & $\%$ \\
\hline Erkek & 24 & 38,09 & Erkek & 18 & 33,3 & Erkek & 3 & 20 \\
\hline Kadın & 39 & 61,91 & Kadın & 36 & 66,7 & Kadın & 12 & 80 \\
\hline Sınıf düzeyi & & & Sinıf düzeyi & & & Sınıf düzeyi & & \\
\hline Beşinci Sınıf & 13 & 20,6 & Beşinci Sınıf & 15 & 27,8 & Beşinci Sınıf & 2 & 13,5 \\
\hline Altıncı sınıf & 11 & 17,25 & Altıncı sınıf & 12 & 22,2 & Altıncı sınıf & 3 & 20,3 \\
\hline Yedinci sınıf & 23 & 36,5 & Yedinci sınıf & 9 & 16,7 & Yedinci sınıf & 4 & 26,5 \\
\hline Sekizinci sınıf & 16 & 25,4 & Sekizinci sınıf & 18 & 33,3 & Sekizinci sınıf & 6 & 39,5 \\
\hline Toplam & 63 & 100 & & 54 & 100 & & 15 & 100 \\
\hline
\end{tabular}

Tablo 1'de görüldüğü üzere araştırma örneklemini oluşturan öğrencilerden memnuniyet anketine katılanlardan dokuz öğrenci ön-teste katılıp son-teste katılmadıkları ya da sadece son-teste 
katıldıklarından dolayı deneysel çalışmadan çıkarılmıştır. Memnuniyet anketine katılan yedinci sınıf öğrencilerinin birçoğu hastalık, ailevi ve özel nedenlerden dolayı uygulama günlerinde okulda bulunmadıklarından dolayı deneysel çalışmada yer almamıştır. Nitel araştırmaya ise hem memnuniyet anketine katılmış hem de İngilizce iletişim istekliliği ölçeğinin ön-test ve son-testinde yer almış gönüllü öğrenciler yer almıştır.

\section{Veri toplama araçları}

Grup içi deneysel araştırmada kullanılan veri toplama aracı Cao ve Philip (2006) tarafından geliştirilmiş 5'li likert tipindeki - Hiçbir zaman (1); Nadiren (2); Ara sıra (3); Sık sık (4); Her zaman (5) - 'Derse İngilizce Katılım İstekliliği’ ölçeğidir. Bu ölçek 16 maddeden oluşmakta ve öğlencilerin sınıf içi çeşitli senaryolarda İngilizce kullanmaya ne kadar istekli olduklarını anlamaya yöneliktir. Ölçeğin orijinal dili İngilizce olduğu için ölçek dil uzmanları tarafından Türkçeye çevrilmiştir ve Türkçe eğitimi alanında çalışan iki uzmanın çeviriye ilişkin görüşüne başvurulmuştur. Uzman görüşleri doğrultusunda ölçekte ilgili kelime ve anlama dayalı düzeltmeler yapılmıştır. İlgili ölçek proje pilot okulunda proje başlamadan önce ve sekiz hafta sonra proje bitiminde öğrencilere dağıtılmıştır. Ölçeğin güvenirlik analizi yapılmış ve analiz sonucunda Cronbach Alfa değeri 0.913 olarak hesaplanmıştır.

Öğrencilerin projede yer almaktan dolayı ne derece memnun olduklarını incelemek amacıyla araştırmacı tarafından ilgili alanyazın, benzeri projelerin içeriği ve özellikle projenin amacı ve kapsamı düşünülerek 16 maddeden oluşan 5'li likert tipinde - Kesinlikle katılmıyorum (1); Katılmıyorum (2); Fikrim yok (3); Katılıyorum (4) ve Kesinlikle katılıyorum (5) - memnuniyet anketi geliştirilmiş. Anket pilot okuldaki proje uygulaması sona erip yabancı öğrencilerin ziyaretleri sonlandığında, okul müdürü ve okulun İngilizce öğretmeni aracılığıyla öğrencilere sınıf ortamında dağıtılmış ve öğrenciler tarafindan yaklaşı 15 dakikada doldurulmuştur.

Son olarak, yukarıda bahsedilen her iki çalışmada yer almış 15 gönüllü öğrenci ile yarı yapılandırılmış görüşmeler yapılmış ve öğrencilerin proje ile ilgili görüşlerine başvurulmuştur. Bu kapsamda, genel hatlarıyla öğrencilere aşağıdaki gibi sorular sorulmuştur:

a. Yabancı öğrencilerle ders işlemekten memnun kaldınız mı? Hangi açılardan (Evet ise) -neden (Hayır ise neden)?

b. Bu öğrencilerle ders işlemenin İngilizce'nize ne tür katkıları olduğunu düşünüyorsunuz?

c. Önümüzdeki dönemlerde de bu ya da başka yabancı öğrencilerle ders işlemek ister misin? Neden?

d. $\mathrm{Bu}$ öğrencilerle iletişiminizi genel olarak nasıl değerlendiriyorsun?

Görüşmeler yarı yapılandırılmış olduğu için görüşmenin gidişatına ve verilen cevapların içeriğine uygun olarak katılımcılara burada yer almayan başka sorular da sorulmuştur. Bununla amaç, katılımcıların projeden memnuniyetlerini daha derinlemesine incelemek ve memnuniyet durumlarındaki bireysel farklılıkları ortaya çıkarmaktır. Bu nedenden dolayı yapılandırılmış bir görüşme yerine yarı yapılandırılmış görüşme formatı benimsenmiştir (Yıldırım ve Şimşek, 2005).

\section{Verilerin analizi}

Verilerin analizinde üç yol izlenmiştir. İngilizce derse katılım istekliliği ölçeği verilerinin analizi Sosyal Bilimler için İstatistik Programı olan SPSS programı aracılığıyla yapılmıştır ve bulgular betimsel ve çıarımsal istatistik analizleri ile sunulmuştur. Çıkarımsal analizlerle amaç, öğrencilerin İngilizce 
katılım istekliklerinde ön-test ve son-test sonuçlarına göre anlamlı bir farkın oluşup oluşmadığını, diğer bir deyişle, yabancı öğrencilerle ders işlemenin öğrencilerin derse katılım istekliliğini arttırıp arttırmadığını saptamaktır (Gürsakal, 2009). Memnuniyet anketinin sonuçları ise sadece betimsel istatistik (frekans, ortalama, standart sapma ve yüzde dağılımı gibi) analizleri ile tablolaştırılarak sunulmuştur (Dörnyei, 2003; Griffee, 2012). Mülakat görüşmeleri ise içerik analizi yöntemi ile analiz edilmiş ve ana ve alt temalar oluşturulmuştur (Schreier, 2012). Elde edilen bulgular bu temalar doğrultusunda anket sonuçları ile ilişkilendirilerek sunulmuştur.

\section{Bulgular ve yorum}

\section{Nicel bulgular}

Çalışmanın birinci araştırma sorusu Burdur merkezde bir ortaokulda öğrenim gören öğrencilerin yabancı öğrenciler eşliğinde ders işlemelerinin derse İngilizce katılım istekliliklerinde olumlu bir etkiye neden olup olmayacağı durumuyla ilgilidir. Çalışmada kullanılan ölçeğin ön-test sonucunda ortaya çıkan sonuçlar incelendiğinde (Tablo 2) öğrencilerin derse İngilizce katılım istekliliklerin oldukça yüksek olduğu söylenebilir. Ölçekte kullanılan 16 maddendin ortalamasının $(\overline{\mathrm{x}}=3.36)$ ara sıra ve sık sık değer aralığında yüksek bir değer olması, öğrencilerin derste İngilizce kullanım istekliliklerin çok düşük olmadığına dayanak sağlamaktadır. 16 madde içerisinde en yüksek ortalama öğrencilerin okullarını ziyaret eden yabancı öğrencilerle konuşma isteklilikleri ile ilgili olan 16 . madde $(\overline{\mathrm{X}}=4,11)$ ve en düşük ortalama ise İngilizce öğretmenlerine ders saatleri dışında İngilizce soru sormayı kapsayan 4. maddedir $(\overline{\mathrm{x}}=2,61)$.

Tablo 2. Derse İngilizce Katılım İstekliliği Ön-test Sonuçları

\begin{tabular}{|c|c|c|c|c|}
\hline Ölçek maddeleri $(\mathrm{N}=54)$ & Min & Mak & Ort. & SS \\
\hline $\begin{array}{l}\text { 1. İngilizce derslerinde öğretmenim sinffta İngilizce soru sorduğunda İngilizce } \\
\text { cevap vermek için gönüllü olmak isterim. }\end{array}$ & 1,00 & 5,00 & 3,62 & 1,24 \\
\hline $\begin{array}{l}\text { 2. İngilizce derslerinde öğretmenim sinffta doğrudan bana soru sorduğunda } \\
\text { İngilizce olarak cevap vermek isterim. }\end{array}$ & 1,00 & 5,00 & 3,68 & 1,07 \\
\hline 3. İngilizce derslerinde veya ders dışında öğretmenimle İngilizce konuşmak isterim. & 1,00 & 5,00 & 3,16 & 1,29 \\
\hline 4. Öğretmenime ders dışında bire bir İngilizce soru sormaya çalışırım. & 1,00 & 5,00 & 2,61 & 1,45 \\
\hline 5. İngilizce derslerinde düşüncelerimi İngilizce olarak söylemeye gayret ederim. & 1,00 & 5,00 & 3,25 & 1,37 \\
\hline 6. İngilizce derslerinde öğretmenime İngilizce soru sormaya çalışırım. & 1,00 & 5,00 & 3,35 & 1,34 \\
\hline 7. İngilizce derslerinde hata yaptığımda İngilizce özür dilerim. & 1,00 & 5,00 & 3,20 & 1,57 \\
\hline $\begin{array}{l}\text { 8. İngilizce derslerinde grup ve eşli çalışmalarda tartışmalara İngilizce katılmak } \\
\text { isterim. }\end{array}$ & 1,00 & 5,00 & 3,20 & 1,53 \\
\hline $\begin{array}{l}\text { 9. İngilizce derslerinde arkadaşlarımın sorulara İngilizce cevap vermesine yardım } \\
\text { etmek isterim. }\end{array}$ & 1,00 & 5,00 & 3,48 & 1,38 \\
\hline 10. Derslerde ve ders dışında İngilizce şarkı söylemek isterim. & 1,00 & 5,00 & 3,24 & 1,56 \\
\hline
\end{tabular}


Students' satisfaction with the 'Interactive English Language Classes' project and the effects of the project on students' willingness to communicate in classes / A. Karakaş (p. 194-213)

\begin{tabular}{|c|c|c|c|c|}
\hline 11. İngilizce derslerinde ders kitabındaki diyalogları sesli olarak okumak isterim. & 1,00 & 5,00 & 3,61 & 1,33 \\
\hline $\begin{array}{l}\text { 12. İngilizce derslerinde arkadaşlarım bana yardım ettiğinde İngilizce teşekkür } \\
\text { etmek isterim. }\end{array}$ & 1,00 & 5,00 & 3,66 & 1,46 \\
\hline $\begin{array}{l}\text { 13. İngilizce derslerinde herhangi bir kaynağa bakmadan kendimi İngilizce } \\
\text { tanıtmak isterim. }\end{array}$ & 1,00 & 5,00 & 3,42 & 1,47 \\
\hline 14. İngilizce derslerinde sınıftaki arkadaşlarımı İngilizce ile selamlamaya çalışırım. & 1,00 & 5,00 & 3,01 & 1,49 \\
\hline $\begin{array}{l}\text { 15. İngilizce derslerinde herhangi bir kaynağa bakmadan derste İngilizce } \\
\text { konuşmaya çalışırım. }\end{array}$ & 1,00 & 5,00 & 3,11 & 1,40 \\
\hline $\begin{array}{l}\text { 16. Okulumuza gelecek yabancı öğrenciler ile derste veya ders dışında İngilizce } \\
\text { konuşmak isterim. }\end{array}$ & 1,00 & 5,00 & 4,11 & 1,25 \\
\hline
\end{tabular}

*1. Hiçbir zaman 2. Nadiren 3. Ara sıra 4. Sik sık 5. Her zaman

Çalışmada kullanılan aynı ölçeğin son test sonuçlarına bakıldığında göze ilk çarpan hemen hemen her maddenin ortalamasında artış olduğudur (bknz. Tablo 3). Ama en şaşırtıcı sonuç, muhtemelen ön-testte en düşük ortalama değere sahip olan İngilizce öğretmenine ders dışında birebir soru sormayı elen alan 4. maddenin son-testte ortalamasının o,61 değerinde artarak 3,22 olmasıdır. Bu sonuca dayanarak öğrencilerin ders dışı saatlerde de proje sayesinde öğretmenleri ile İngilizce iletişim kurma istekliliklerin süreklilik kazandığı yorumu yapılabilir. Diğer bir ilginç sonuç ise, derste hata yapılan durumlarda İngilizce özür dilemeyle ilgili 7. maddenin ön-test ortalama değerinin $(\overline{\mathrm{x}}=3,20)$ son-test ortalama değerinden $(\overline{\mathrm{x}}=3,16)$ sayısal olarak çok az da olsa daha fazla olmasıdır. Ayrıca, ön-test sonuçlarıyla kıyas edildiğinde ortalamalardaki en fazla artış (o,92 puan ile) öğrencilerin ders içi ve dışında İngilizce şarkı söyleme istekliliklerine değinen 10. maddede gözlenmiştir. 10. maddenin ortalaması son-testte elde edilen en yüksek değerdir. Aşağıda da görüleceği üzere, bahsedilen maddelerin dışındaki maddelerde de ön-test sonuçlarıyla karşılaştırıldığında son-test sonuçlarında çeşitli miktarlarda artışlar olmuştur.

Tablo 3. Derse İngilizce Katılım İstekliliği Son-test Sonuçları

\begin{tabular}{|c|c|c|c|c|}
\hline Ölçek maddeleri $(\mathrm{N}=54)$ & Min & Mak & Ort. & SS \\
\hline $\begin{array}{l}\text { 1. İngilizce derslerinde öğretmenim sınıfta İngilizce soru sorduğunda İngilizce } \\
\text { cevap vermek için gönüllü olmak isterim. }\end{array}$ & 1,00 & 5,00 & 3,68 & 1,11 \\
\hline $\begin{array}{l}\text { 2. İngilizce derslerinde öğretmenim sinıfta doğrudan bana soru sorduğunda } \\
\text { İngilizce olarak cevap vermek isterim. }\end{array}$ & 1,00 & 5,00 & 3,96 & 1,13 \\
\hline 3. İngilizce derslerinde veya ders dışında öğretmenimle İngilizce konuşmak isterim. & 1,00 & 5,00 & 3,50 & 1,16 \\
\hline 4. Öğretmenime ders dışında bire bir İngilizce soru sormaya çalışırım. & 1,00 & 5,00 & 3,22 & 1,39 \\
\hline 5. İngilizce derslerinde düşüncelerimi İngilizce olarak söylemeye gayret ederim. & 1,00 & 5,00 & 3,74 & 1,21 \\
\hline 6. İngilizce derslerinde öğretmenime İngilizce soru sormaya çalışırım. & 1,00 & 5,00 & 3,68 & 1,21 \\
\hline 7. İngilizce derslerinde hata yaptığımda İngilizce özür dilerim. & 1,00 & 5,00 & 3,16 & 1,45 \\
\hline
\end{tabular}




\begin{tabular}{|c|c|c|c|c|}
\hline $\begin{array}{l}\text { 8. İngilizce derslerinde grup ve eşli çalışmalarda tartışmalara İngilizce katılmak } \\
\text { isterim. }\end{array}$ & 1,00 & 5,00 & 3,61 & 1,23 \\
\hline $\begin{array}{l}\text { 9. İngilizce derslerinde arkadaşlarımın sorulara İngilizce cevap vermesine yardım } \\
\text { etmek isterim. }\end{array}$ & 1,00 & 5,00 & 3,72 & 1,33 \\
\hline 10. Derslerde ve ders dışında İngilizce şarkı söylemek isterim. & 1,00 & 5,00 & 3,75 & 1,41 \\
\hline 11. İngilizce derslerinde ders kitabındaki diyalogları sesli olarak okumak isterim. & 1,00 & 5,00 & 4,16 & 1,16 \\
\hline $\begin{array}{l}\text { 12. İngilizce derslerinde arkadaşlarım bana yardım ettiğinde İngilizce teşekkür } \\
\text { etmek isterim. }\end{array}$ & 1,00 & 5,00 & 3,79 & 1,30 \\
\hline $\begin{array}{l}\text { 13. İngilizce derslerinde herhangi bir kaynağa bakmadan kendimi İngilizce } \\
\text { tanıtmak isterim. }\end{array}$ & 1,00 & 5,00 & 3,61 & 1,13 \\
\hline 14. İngilizce derslerinde sınıftaki arkadaşlarımı İngilizce ile selamlamaya çalışırım. & $1, \mathrm{OO}$ & 5,00 & 3,12 & 1,38 \\
\hline $\begin{array}{l}\text { 15. Ingilizce derslerinde herhangi bir kaynağa bakmadan derste İngilizce } \\
\text { konuşmaya çalışırım. }\end{array}$ & 1,00 & 5,00 & 3,31 & 1,25 \\
\hline $\begin{array}{l}\text { 16. Okulumuza gelecek yabancı öğrenciler ile derste veya ders dışında İngilizce } \\
\text { konuşmak isterim. }\end{array}$ & 1,00 & 5,00 & 4,11 & 1,14 \\
\hline
\end{tabular}

*1. Hiçbir zaman 2. Nadiren 3. Ara sıra 4. Sik sık 5. Her zaman

Yukarıdaki tablolarda sunulan verilerden anlaşlacağı üzere öğrencilerin derse İngilizce katılım isteklikleri sekiz haftalık uygulama sonunda belirli miktarlarda artmıştır. Ama bu artışın istatiksel olarak anlamlı olup olmadığını Tablo 2 ve 3'teki verilere dayanarak anlamak mümkün değildir. $\mathrm{Bu}$ nedenle çıkarımsal istatistik tekniklerinden biri olan İlişkili (bağımlı) örneklem T-testi ile öğrencilerin ön-test ve son-test ortalamaları karşılaştırılmıştır. Yabancı öğrencilerin derslere girmeye başlaması öncesinde ve sonrasında uygulanan derse İngilizce katılım istekliliği ölçeğinin ortalamaları arasında bir fark olup olmadığını belirlemek için yapılan ilişkili örneklemler için t-testi sonucunda $[\mathrm{t}(53)=-2.806$, p<0,05] yabancı öğrencilerin ziyareti öncesinde elde edilen ölçek ortalaması ile ziyaret sonrası elde edilen ölçek ortalamaları arasında anlamlı bir fark görülmüştür. Bu durum, söz konusu ortaokul öğrencilerinin, İngilizce derslerini yabancı öğrenciler eşliğinde işlemelerinin İngilizce iletişim istekliliklerinin artmasında anlamlı bir etkisinin olduğunu göstermektedir. İlgili testin sonuçları Tablo 4'te sunulmuştur.

Tablo 4. İlişkili (Bağımlı) Örneklem T-testi sonuçları

\begin{tabular}{lllllll}
\hline ÖLÇÜM & $\mathrm{N}$ & $\overline{\mathrm{x}}$ & $\mathrm{S}$ & $\mathrm{sd}$ & $\mathrm{t}$ & $\mathrm{p}$ \\
\hline Ön-test & 54 & 3.36 & 0.96 & 53 & -2.806 & 0.007 \\
Son-test & 54 & 3.63 & 0.83 & & & \\
\hline
\end{tabular}

Çalışmanın ikinci araştırma sorusunun - öğrencilerin yabancı öğrencilerle ders işleme ve projede yer almaları ile ilgili olarak ne derece memnun oldukları - cevaplandığı anket sonuçlarına göre, öğrencilerin yabancı öğrencilerle ders işlemekten birçok açıdan oldukça memnun oldukları anlaşılmaktadır (bknz. Tablo 5). Ankette yer alan 16 maddenin ortalamasının 3,85 olması da sayısal olarak öğrencilerin proje kapsamında yabancı öğrenciler eşliğinde İngilizce derslerini işlemekten ne kadar memnun olduklarını göstermektedir. 
Tablo 5. Memnuniyet anketi sonuçları

\begin{tabular}{|c|c|c|c|c|}
\hline Anket maddeleri $(\mathrm{N}=63)$ & Min & Mak & Ort. & SS \\
\hline 1. Yabancı öğrenciler mükemmel ve burada onlarla ders işlemekten mutluyum. & 1,00 & 5,00 & 4,33 & ,96 \\
\hline 2. Yabancı öğrencilerden çok şey öğrendiğimi düşünüyorum. & 1,00 & 5,00 & 3,85 & 1,14 \\
\hline 3. Daha fazla yabancı öğrenci okulumuza gelip derse girse mutlu olurum. & 1,00 & 5,00 & 4,11 & 1,25 \\
\hline 4. Yabancı öğrencilerin konuşma becerim için faydalı olduğunu düşünüyorum. & 2,00 & 5,00 & 4,12 &, 87 \\
\hline $\begin{array}{l}\text { 5. Daha önce yabancı öğrenciler derslerimize gelseydi İngilizcem çok daha iyi } \\
\text { olabilirdi. }\end{array}$ & 1,00 & 5,00 & 3,60 & 1,27 \\
\hline $\begin{array}{l}\text { 6. Yabancı öğrenciler sayesinde İngilizcenin farklı kültür ve dillerden insanlar } \\
\text { tarafindan da konuşulduğunu fark ettim. }\end{array}$ & 1,00 & 5,00 & 3,85 & 1,20 \\
\hline 7. Yabancı öğrenciler sayesinde İngilizce konuşmak için gerçek bir nedenim oldu. & 1,00 & 5,00 & 3,96 &, 94 \\
\hline $\begin{array}{l}\text { 8. Önümüzdeki yıllarda da yabancı öğrencilerin okulumuza gelmesi bizler için } \\
\text { faydalı olacaktır. }\end{array}$ & 1,00 & 5,00 & 4,00 & 1,17 \\
\hline 9. Yabancı öğrenciler daha fazla derslerimize gelse mutlu olurum. & 1,00 & 5,00 & 4,01 & 1,23 \\
\hline $\begin{array}{l}\text { 10. Yabancı öğrencilerle ile İngilizce öğrenmek daha ilgi çekici ve zevkli hale } \\
\text { geliyor. }\end{array}$ & 1,00 & 5,00 & 4,07 & 1,26 \\
\hline $\begin{array}{l}\text { 11. Yabancı öğrencilerin gelmesi ile birlikte sınıfımızda İngilizce' ye olan ilginin } \\
\text { arttığını düşünüyorum. }\end{array}$ & 1,00 & 5,00 & 3,76 & 1,24 \\
\hline 12. Yabancı öğrencileri anlamakta bazen güçlük çektiğimi düşünüyorum. & 1,00 & 5,00 & 3,22 & 1,31 \\
\hline $\begin{array}{l}\text { 13. Yabancı öğrencilerle ders işledikten sonra ben de Türkiye dışında İngilizceyi } \\
\text { kullanabileceğimi fark ettim. }\end{array}$ & 1,00 & 5,00 & 3,65 & 1,17 \\
\hline $\begin{array}{l}\text { 14. Yabancı öğrencilerle işlemiş olduğum derslerin çok faydalı olduğunu } \\
\text { düşünmüyorum. }\end{array}$ & 1,00 & 5,00 & 3,53 & 1,37 \\
\hline $\begin{array}{l}\text { 15. Yabancı öğrencilerle birlikte ilk defa gerçek anlamda İngilizce kullandığımı } \\
\text { düşünüyorum }\end{array}$ & $1, \mathrm{OO}$ & 5,00 & 3,63 & 1,24 \\
\hline $\begin{array}{l}\text { 16. Bu tür uygulamaların diğer sınıflarda da olması öğrencilerin motivasyo } \\
\text { arttıracaktır. }\end{array}$ & $1, \mathrm{OO}$ & 5,00 & 3,93 & 1,36 \\
\hline
\end{tabular}

*1 Kesinlikle katılmıyorum; 2 Katılmıyorum; 3 Fikrim yok; 4 Katılıyorum ve 5 Kesinlikle katılıyorum

Tablo 5 'ten anlaşlacağı üzere, en yüksek skora sahip ilk 5 maddenin ortalamaları 4,o veya üzerinde bir değerdedir. Bu maddeler sirasiyla 4. madde, 3. madde, 10. madde, 9. madde ve 8. maddelerdir. Bu maddelerden anlaşılacağı üzere, öğrenciler yabancı öğrencilerle ders işlemenin konuşma becerilerini geliştirme açısından önemli olduğunu, okullarına daha fazla yabancı öğrencinin gelmesinin kendilerini mutlu edeceğini, bu öğrenciler eşliğinde işlenen derslerin daha zevkli ve eğlenceli geçtiğini ve uygulamanın ilerleyen yıllarda devam etmesinin kendileri için İngilizce dil becerileri açısından faydalı olacağını düşünmektedirler. Üstelik yabancı öğrencilerle ders işlemenin birçok öğrencinin İngilizce derslerine ilgisini ve dil konuşmaya yönelik motivasyonunu arttırdığı da söylenebilir (11. ve 16. maddeler).

Bunlara ek olarak, anket verilerine göre, projede yer almanın öğrencilerin İngilizce'nin günümüzdeki konumuyla ve İngilizce konuşan bireylerin sosyokültürel profilleri ile ilgili farkındalıklarını arttırdığı ve öğrencilerin ‘İngilizce ne işime yarayacak' sorusuna anlamlı bir cevap bulmalarına yardımcı olduğu söylenebilir. Bu bağlamda, birçok öğrenci yabancı öğrencilerle ders işlerken gerçek anlamda ilk defa İngilizce kullanma ihtiyacı hissettiklerini (15. Madde, $\overline{\mathrm{x}}=3,63$ ), kendilerinin de yurtdışına gitmeleri durumunda iletişim için İngilizce kullanma gerekliliklerinin olabileceğini (13. Madde, $\overline{\mathrm{x}}=3,65$ ) ve 
İngilizce'nin birçok farklı dil ve kültürden insanın konuştuğu evrensel bir dil haline (6. Madde, $\overline{\mathrm{x}}=3,85$ ) geldiğini belirtmişlerdir.

Ankette ortalaması en düşük madde, öğrencilerin yabancı öğrencililerle ileteşimde zorluk çekip çekmediklerini belirlemeye çalışan 12. maddedir. Bu maddenin ortalaması bize öğrencilerin birçoğunun iletişim sıkıntısı yaşamadan kendi seviyeleri doğrultusunda yabancı öğrencilerle anlaşabildiklerini göstermektedir. Son olarak, yukarıdaki verilerden anlaşlacağı üzere, büyük bir öğrenci grubu bu tür bir projenin daha önceden uygulanmış olması durumunda yabancı öğrencilerden dil becerileri açısından çok fazla istifade edebildiklerinden dolayı İngilizce becerilerinin mevcut durumdan çok daha iyi düzeyde olabileceğini aktarmıştır (2. ve 5. maddeler). Tüm bu veriler projenin öğrenciler üzerinde duyuşsal (motivasyon, mutluluk, isteklilik) bilişsel (dil kullanım alanları ve dilin kullanılabileceği kişiler üzerine yansıtıcı düşünme) ve davranışsal (benzer projelerde yer alma arzusu, Türkiye dışında dil kullanma isteği) açıdan dil kullanımı ile ilgili olumlu katkıları olduğunu gösterir niteliktedir.

\section{Nitel bulgular}

Çalışmanın nitel bölümünde üçüncü araştırma sorusu olan öğrencilerin yabancı öğrenciler eşliğinde ders işlemelerine ilişkin görüşleri nelerdir sorusunda cevap aranmıştır. Bu kapsamda öğrencilere birebir görüşmelerde sormuş olduğumuz sorulara verdikleri cevaplar analiz edilmiştir. Bu bağlamda öğrencilere öncelikle yabancı öğrencilerle ders işlemekten memnun olup olmadıkları ve bu derslerden hoşlanıp hoşlanmadıkları sorulmuştur.

15 öğrencinin tamamı, aşağıda içerik analizi ortaya çıkarılan temalarla ilgili olarak projeden ve projenin bir parçası olmaktan oldukça hoşnut olduklarını söylemişlerdir. Tablo 6'da görüleceği üzere öğrencilerin projeden memnuniyetleri 5 tema altında toplanmıştır. Bu temalar kodların hiyerarşik yapısına göre sunulmuştur. Bu kapsamda en fazla kod 'eğlence faktöründe' en az ise ‘iyi ilişkiler kurabilme’ temasında ortaya çıkmıştır.

Tablo 6. Yabancı öğrencilerle ders işleme memnuniyetinin nedenleri

\begin{tabular}{ll}
\hline Ana temalar & Alt temalar \\
\hline Eğlence faktörü & Oyun oynama \\
& Şarkı dinleme ve söyleme \\
Dil kullanım fırsatı & Soru sorma \\
& Diğer öğrencilere yardımcı olma \\
Dile karşı olumlu tutumlar & Yabancı öğrencilere karşı beslenen sevgi \\
& Dile karşı oluşan olumlu tutumlar \\
İyi ilişkiler kurabilme & Ö̆̆grenci dostu yaklaşım \\
\hline
\end{tabular}

Ĕğlence faktörü: Katılımcı öğrencilerin tamamı dersleri yabancı öğrenciler eşliğinde işlemenin derslerini daha eğlenceli ve zevkli hale getirdikleri dile getirmişlerdir. Bu öğrencilerin ders içerisinde sık sık oyun oynattıkları, şarkılar dinletip öğrencilere şarkılar söylettikleri ve genel olarak dilbilgisi öğretiminden uzak durdukları belirtilmiştir. Bu konuyla ilgili olarak bazı öğrencilerin ifadeleri aşağıdaki gibidir: 
Students' satisfaction with the 'Interactive English Language Classes' project and the effects of the project on students' willingness to communicate in classes / A. Karakaş (p. 194-213)

Ö1: Hem İngilizce dersini sevdiğim için İngilizcem iyi. Hem onlarla oyun oynuyorduk.

Ö4: Mesela oyun oynatmaları, bize sorular sormaları açısından memnun kaldım.

Ö12: Böyle çok güzel şeyler öğretiyorlar. Hem öğretiyorlar bir de oyun oynatıyorlar öğretirken.

Ö15: Oyun oynadık, şarkı dinledik ve şarkı söylettiler başkada bir şey yapmadık.

Dil kullanım firsatt: Eğlence boyutuna ek olarak çoğu öğrenci yabancı öğrenciler sayesinde hem dil kullanma hem de bu şekilde dil becerilerini geliştirme fırsatı yakaladıklarını söylemişlerdir. Bu temada yer alan bazı ifadelerin eğlence faktöründe belirtilen bazı ifadeleri de içerdiği görülmüştür. Aşağıda bu temayla ilgili bazı öğrenci açıklamaları yer almaktadır:

Ö2: Daha eğlenceli oldu ders. Onlarla konuşmak İngilizcemi geliştirdi

Ö3: Yabancı [İngilizce] konuşmamız ve oyun oynamamız dilimizi geliştirdi.

Ö14: İngilizce konuşarak oyunlar oynadı, kendimizi tanıttık ve onlara sorular sorduk.

Dile karşı olumlu tutumlar: Dile karşı olumlu tutum sergileme dil öğreniminin öncülleri arasındadır. Projenin bu noktada öğrencilere dili ve dil kullanımını sevdirmesi dikkat çekici bir noktadır.

Ö6: Hem yabancı öğretmenleri seviyorum hem de yabancı konuşmayı çok severim.

Ö8: Yabancı öğrencilerin ziyaretleri hoşuma gitti mutlu oldum, seviyorum zaten İngilizce dersini.

Ö11: Önceden İngilizceyi fazla sevmiyordum, şimdi çok seviyorum.

Ö13: Daha çok sevdim İngilizceyi hem yabancı öğrenciler geldiğinde çok sevdim yabancı öğrencileri.

İyi ilişkiler kurabilme: Öğrencilerle yakınlık kurabilmek bir önceki tema kadar dil öğreniminde önem arz etmektedir. Bazı durumlarda öğrenciler ilgili derste akademik olarak başarılı olmasalar bile öğretmenlerine karşı yakınlık hissettiklerinden dolayı derse karşı ekstra hazırlık ve öğrenme çabası içine girebilmektedirler. Bu noktada projenin öğrenme ve öğretmenle iyi ilişkiler fırsatı vermesi gayet olumlu bir gelişmedir.

Ö10: Şimdi biz onlarla Türkçe konuşurken onlar çok yanlıs söylüyordu. Onlar da bize İngilizce kelimeler öğretmeye çalıșıyordu biz de onları yanlıs söylüyorduk o sırada birbirimizin dillerini çok iyi öğrenemediğimizi öğrendik ama sonradan toparladık. Sadece öğretmen gibi değiller biz de onlara bir şeyler öğretiyorduk.

Ö13: Hem bize iyi davranıyorlar bir de bizimle hep böyle şey oyun oynuyorlar. Arkadaş gibiler.

Öğrencilerle görüştüğümüz diğer bir konu ise yabancı öğrencilerle ders işlemenin dil gelişimlerine ve akademik başarılarına bir katkısı olup olmadığı konusuydu. Bu konuyla ilgili olarak iki öğrenci hariç tüm öğrenciler yabancı öğrenciler ile ders işlemenin İngilizce dil becerilerine olumlu katkılar yaptığını belirtmiştir. Bu konuya ilgili ana ve alt temalar aşağıdaki tabloda sunulmuştur.

Tablo 7. Projenin öğrencilerin İngilizce becerilerine katkıları ile ilgili görüşler

\begin{tabular}{ll}
\hline Ana temalar & Alt temalar \\
\hline Dil becerilerinin gelişimi & Kelime öğrenimi \\
& Konuşma becerisi \\
Akademik başarı & Not artışı \\
\hline
\end{tabular}

Dil becerilerinin gelişimi: Öğrenciler genel olarak yabancı öğrenciler ile ders işlemenin özellikle kelime öğrenimlerini ve başta telaffuz olmak üzere konuşma becerilerini geliştirdiğini ifade etmişlerdir. Ayrıca katılımcı öğrenciler yabancı öğrencilerin dil öğretirken geleneksel öğretim yöntemlerinden ziyade 
yenilikçi öğretim yaklaşımlarından ve çeşitli dil öğretim stratejilerinden faydalandıklarını dile getirmişlerdir. Bu konuyla ilgili olarak bazı katılımcılar aşağıdaki açıklamalarda bulunmuşlardır:

Ö1: Mesela ben "ask" kelimesini bilmiyordum. "Ask" soru sormak ya, ben onu bilmiyordum. Dedim ki "İkinci ders burada olacak mısınız? " Onlar da "Yasemin Hoca'ya soralım" 1 İngilizce dediği için oradan öğrendim.

Ö2: İngilizcedeki kelimeleri kodlayarak daha iyi tutabildim aklımda.

Ö6: İngilizce konuşmamı daha çok geliştirdi. Konuşmam değişti daha çok iyi konuşuyorum.

Ö10: Şimdi onlar yani bize Türkçeyi konuşamıyordu biz de onlarla çok İngilizce konuşamıyorduk merhaba, günaydın, iyi akşamlar yani böyle şeyler konuşuyorduk şimdi mesela her şeyini sorabiliyorsun.

Ö12: Birazcık kelimeleri tam söyleyemiyordum artık bazılarını söylüyorum.

Akademik başarı: İki öğrenci ise yabancı öğrenciler ile ders işlemenin akademik başarılarına olumlu olarak etki ettiğini söylemiştir. Muhtemelen buradaki ana unsur öğrencilerin yabancı öğrenciler ile ders işlemesinin kendilerinde İngilizce’ye karşı olumlu güdülenme oluşturmuş olma olasılığıdır.

Ö3: Onlarla ders yaptıktan sonra sinavlarda notlarım yükseldi.

Ö9: Derslere daha çok katılmaya başladım. Yani biraz İngilizceyi daha çok öğrendim ben.

Projede olumlu anlamda istifade edemediğini belirten iki öğrenci bunun nedenini şu şekilde açıklamışlardır:

Ö6: Bana çok bir katkısı oldu diyemem. İngilizceyi ben sevmiyorum zaten o yüzden.

Ö8: İngilizce dersini seviyorum ama notum düştü. Çok değil, çok konuşamıyorum. İngilizcem çok iyi değil.

Sonraki dönemlerde de yabancı öğrenciler ile ders işlemeyi isteyip istemedikleri sorusuna yine yukarıdaki cevaplara benzer şekilde istisnasız tüm öğrenciler 'Evet' yanıtı vermiştir. Tema olarak iki ana konu ön plana çıkmıştır. Bunlardan ilki ilk soruda da yaygın olarak ortaya çıkan 'eğlence/eğlenme' faktörüdür. Bu temaya ilgili olarak öğrenciler hem yabancı öğrencileri hem de İngilizce derslerini çok sevdiklerini, derslerinin çok eğlenceli ve zevkli hale geldiğini ifade etmişler ve tüm bu nedenlerden dolayı ilerleyen dönemlerde de benzeri uygulamaların okullarında devam etmesini istemişlerdir. Bir iki öğrenci ise eğlenmenin dışında dil becerilerinin daha da gelişeceği ve akademik başarılarının artacağı öngörüsüyle yabancı öğrencilerle sonraki dönemlerde de birlikte olmak istediklerini söylemişlerdir.

Ö1: Seviyorum yani yabancı öğretmenleri.

Ö2: Çünkü çok eğlenceliler. Çok tatlllar ve çok güzel eğlendiriyorlar.

Ö3: Eğlendiğimiz için, biraz daha anladığım için ve notlarım yükseldiği için.

Ç6: Yabancı öğretmenleri sevdiğim için.

Ö10: İsterdik onlarla ders işlemesi yani bizim hoşumuza gidiyor.

Ö13: Hem biraz daha İngilizcemi geliştirmiş olurum diğer dönemlerde.

Son olarak, yabancı öğrencilerle iletişimleri ile alakalı görüşlerini belirtirken çoğu öğrenci problem yaşamadan iletişim kurabildiklerini, rahat hareket edebildiklerini, zamanla onlara daha fazla soru sorup konuşabildiklerini ve utangaçlık duygularından kurtulup daha fazla etkileşim içinde bulunduklarını dile getirdiler. 
Students' satisfaction with the 'Interactive English Language Classes' project and the effects of the project on students' willingness to communicate in classes / A. Karakaş (p. 194-213)

Ö1: Genellikle iyiydi yani. Mesela Pierre abi, Larissa abla hasta olduğundan gelmemişti. Biz oyun oynuyorduk, adı Bingo'ydu herhalde. Biz onunla oyunu anlamayanlara anlatmaya çalışıyorduk. O bazı kelimeleri bilmediği için ben yardımcı oluyordum anlatmasına.

Ö4: Normal, bize İngilizce konuşuyorlar. İngilizce konuşuyorduk.

Ö10: İlk başta çok zorlanıyorduk şimdi normal bu şekilde.

Ö14: İlk geldiklerinde biraz konuşmuyorduk biraz utandık fakat sonra konuşmaya başladık.

Bazı öğrenciler ise iletişim kurarken biraz zorlandıklarını bunun da kendi İngilizce seviyelerinin ve dile karşı tutumlarının olumsuz olmasından kaynaklandığını belirtmişlerdir.

Ö7: Şey azıcık İngilizce konuşamasak da yine biraz konuşuyoruz. İngilizceyi ben çok sevmiyorum.

Ö8: Çok değil, çok konuşamıyorum. Daha çok İngilizcesi iyi olan arkadaşlarım konuştu onlarla.

Bir öğrenci ise çok farklı bir noktaya dikkat çekerek yabancı öğrencilerle etkileşimde bulunmanın kendisinde İngilizce'nin mevcut statüsü ile ilgili farkındalık oluşturduğunu, İngilizce'nin günümüzde düşündüğünden daha önemli hale geldiğini anladığını belirtmiştir.

Ö10: biz şimdi İngilizceyi tek bir dil olarak düşünüyorduk yani basit bir dil olarak ama şimdi dünya genelinde bir dil oldu.

Son olarak, nitel verilerin nicel veri analizinde ortaya çıkan derslerin zevkli hale gelmesi, öğrencilerin

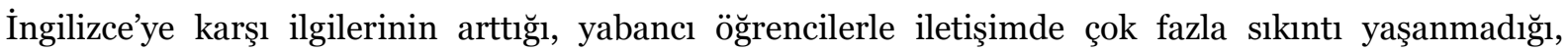
İngilizce'nin mevcut statüsünün öğrenciler tarafından anlaşılması, projenin devam etmesiyle yabancı öğrencilerin İngilizce gelişimlerine daha fazla katkı sağlayacakları gibi bulguları desteklediği söylenebilir.

\section{Tartışma ve sonuç}

Bu çalışmada, Burdur il Milli Eğitim Müdürlüğü ve MAKÜ Eğitim Fakültesi işbirliği ile yürütülen 'Etkileşimli İngilizce Dil Sınıf' projesinin pilot uygulamasında yer alan ortaokul öğrencilerinin proje sayesinde İngilizce iletișim istekliliklerin artıp artmadığı, projeden ne derece memnun kaldıkları ve projede yer alan yabancı öğrenciler ile ders işleyişleri ile ilgili algı ve düşünceleri incelenmiştir. Çalışmanın bulguları, yabancı öğrenciler eşliğinde ders işlemenin öğrencilerin derse İngilizce katılım istekliliğini istatistiki anlamda olumlu olarak arttırdığını göstermiştir. Bu sonuç MEB'in 2011'de gerçekleştirmeye çalıştı̆̆ benzeri projelerde genellikle ana dili İngilizce olan kişilerin yer almış olduğu sınıflarda öğrencilerin dersleri motive edici ve ilgi çekici buldukları ve bu nedenle derslere katılımlarının arttığı sonucu ile açıklanabilir (bknz. Charles, 2006; Lin, 2001). Mevcut çalışmada yer alan yabancı öğrencilerden sadece biri anadil olarak İngilizce konuşurken diğer yabancı öğrenciler farklı millet ve dillerden gelmektedir. Ama görülüyor ki, Aydın (2017), Şener (2014) ve Hişmanoğlu ve Özüdoğru'nun (2017) İngilizce iletişim istekliliği üzerine yaptıkları çalışmaların sonuçlarına paralel olarak dersteki aktiviteler, yabancılara ve yabancı dile karşı olumlu tavır ve tutum ve İngilizce konuşan bireylerle ilk elden etkileşim, konuşulan kişiler ana dili İngilizce konuşanlar olsun ya da olmasın, öğrencilerin derse İngilizce katılım istekliliğini olumlu olarak etkilemiştir.

Mevcut çalışma ayrıca hem MEB'in 2011'de hayata geçirmek istediği hem de özellikle Doğu Asya ülkelerinde yürütülen dil projelerinden farklıdır. En önemli fark diğer projelerin çok maliyetli olması ve tamamen ana dili İngilizce olan kişilerin işe alınarak projelere dâhil edilmesinden oluşmaktadır. Bu projede ise hiçbir maliyet söz konusu değildir ve tamamen yabancı öğrencilerin gönüllülük esasına göre haftada bir iki saat, önceden belirlenen okullarda, derslerde okulların İngilizce öğretmenlerine eşlik 
etmelerini içermektedir. Projede yer alan yabancı öğrencilerin gönüllülük esasına göre ve isteyerek okullarda bulunmaları ve hâlihazırda öğretmen adayı olmaları da yaptıkları işi severek yapmalarına neden olmuş olabilir. Bu da öğrencilerde karşlık görmüş ve derslere daha fazla katılım gösterme istekliliği olarak kendini göstermiş olabilir.

Çalışma sonuçları ayrıca öğrencilerin birçok konuda projeden ve yabancı öğrencilerle ders işlemekten bir hayli memnun olduklarını göstermiştir. Özellikle nitel verilerin analizi öğrencilerin yabancı öğrenciler ile ders işlemeyi çok eğlenceli, zevkli ve rahat bir hale getirdiğine inandıklarını göstermiştir. Bu sonuç daha önce yapılan benzeri çalışmalarda elde edilen, öğrencilerin yabancı hocaların daha arkadaş canlısı oldukları, daha işlevsel İngilizce kullandıkları ve anadili İngilizce olmayan öğretmenlere kıyasla daha esnek oldukları, bulgusunu destekler niteliktedir (bknz. İnceçay ve Atay, 2009; Karakaş, Uysal, Bilgin ve Bulut, 2016; Wu ve Ke, 2009). Bu sonucun ortaya çıkmasına neden olan bir başka etken ortaokul öğrencilerinin yabacı öğrencilerle dilbilgisi öğreniminden ziyade göreve dayalı öğrenme (task based learning) yaklaşımıyla etkileşimi gerektiren gerçek ve anlamlı görevlerle dersleri işlemiş olmaları olabilir (Larsen-Freeman ve Anderson, 2011; Richards ve Rodgers, 2014). Ek olarak derslerde öğrenci kaygısını ve öğrenmeye yönelik kısıtlamayı ortadan kaldıran yani bir anlamda duyuşsal etkenlerin olumsuz etkilerini minimize eden şarkı söyleme, dinleme ve oyun oynama gibi aktiviteler öğrencilerin derslerden ve yabancı öğrencilerden memnun kalmasına sebep olmuş olabilir. Krashen'ın (1982) dil edinimi süreci üzerine beş hipotezinden biri olan ‘duyuşsal filtre hipotezinde’ belirttiği gibi öğrencilerin motivasyonun artması, öz-güvenlerinin yükselmesi ve kaygı seviyelerinin düşmesi dil öğrenim sürecine olan bakış açılarını olumlu olarak değiştirmiş olabilir.

Mevcut çalışma, derse İngilizce katılım istekliliği, projeden memnuniyet ve proje ile ilgili genel görüşleri pilot uygulamada yer alan öğrencilerin bakış açısıyla incelemesi yönüyle, sadece projenin uygulandığı ortaokuldaki öğrencilerin cevaplarıyla sınırlıdır. Bu projede yer almış ve yabancı öğrencileri derslerinde misafir etmiş olan okulların İngilizce öğretmenlerinin, okul idarecilerinin ve proje kapsamında okulları ziyaret eden yabancı öğrencilerin de tecrübe ve deneyimleriyle beraber görüşlerine yönelik ek çalışmalar ilerleyen dönemlerde yapılabilir. Ayrıca bu çalışmada, öğrencilerin derse İngilizce katılım istekliliği açısından cinsiyet ve sınıf gibi değişkenler açısından farklı algılamalar olup olmadığına odaklanılmamıştır. Bu projede yer alan çeşitli okullardaki öğrenciler üzerine yapılabilecek başka bir çalışmada bu durum bir alt problem olarak benimsenebilir ve buna yönelik ek çalışmalar tekrar proje ekibinden araştırmacılar tarafından ilerleyen dönemlerde yapılabilir.

Son olarak, araştırmanın sonuçlarına dayanarak İngilizce öğretiminde benzeri proje ve uygulamalara yönelik bazı önerilerde bulunulabilir. Burdur MAKÜ henüz yeni bir üniversite olmasından ve Burdur'un küçük bir il olmasından dolayı Türkiye'de bazı illerdeki üniversiteler kadar yabancı öğrenci çekememektedir. $\mathrm{Bu}$ nedenle büyük illerimizdeki üniversitelerde ve benzeri küçük illerdeki üniversitelerde benzer projeler hayata çok daha rahat geçirilebilir. İllerdeki il milli eğitim müdürlükleri aracılı̆̆ıla özellikle dezavantajlı bölgedeki okullara yabancı öğrenciler gönderilebilir. Bu tür uygulamalar sahil şeridinde yer alan turistik şehirlerimizde öğrencilerin dil kullanım firsatlarının fazla olması sebebiyle daha fazla ilgisini çekebilir. Bu ve benzeri projeler, MEB'in (2018) ilkokul ve ortaokul İngilizce dersi öğretim programında İngilizce öğretiminde öncelikle amaç olarak belirttiği İngilizce öğrenimine karşı öğrencilerde olumlu tutum geliştirme hedefine ulaşılmasını kolaylaştırabilir. 


\section{Teşekkür}

Etkileşimli İngilizce Dil Sınıfı projesinin proje ortağı kurum yetkilisi Burdur Mehmet Akif Ersoy Üniversitesi Eğitim Fakültesi dekanı Sayın Prof. Dr. Sibel Karakelle’ye, proje sahibi kurum yetkilisi Burdur İl Milli Eğitim müdürü Sayın Mahmut Bayram’a projeye vermiş oldukları desteklerinden dolayı, ve projenin uygulandı̆̆ı kurumun yetkilisi olan Türkiye Yardım Sevenler Ortaokul müdürü Sayın Gülizar Güzel'e ve projenin uygulandığı kurumun irtibat kişisi İngilizce Öğretmeni Sayın Yasemin Çakıcı'ya projenin yürütülmesinden sonlandırılmasına kadar olan tüm katkılarından dolayı teşekkür ederim. Ek olarak, alanyazınla ilgili makale taramasında yardımlarını esirgemeyen MAKÜ İngiliz Dili Eğitimi öğrencisi Özlem Karagünli’ye ve nicel verilerin işlenmesinde ve analizinde vermiş olduğu destekten dolayı Dr. Gürcan Kaya'ya çok teşekkür ederim. Son olarak, projede yer alan tüm İngilizce öğretmenlerimize ve yabancı uyruklu öğrencilerimize bu projeyi hayata geçirmemize yardımcı oldukları için canı gönülden teşekkürlerimi sunarım.

\section{Kaynakça}

40 bin yabancı öğretmen geliyor. (2019, Mart 19). Hürriyet. Erişim adresi http://www.hurriyet.com.tr/gundem/40-bin-yabanci-ogretmen-geliyor-17312507

Akbay, T. (2019). Deneysel araştırmalar. S. Şen ve İ. Yıldırım (Yay. haz.) Ĕ̆itimde Araştırma Yöntemleri (s. 155-179). Ankara: Nobel Akademik Yayıncılık.

Allen, M. (Ed.). (2017). The SAGE encyclopedia of communication research methods. SAGE Publications.

Arkan, A. (2017). English language teachers' views on the new national curriculum for 2nd graders. Journal of Narrative and Language Studies, 5(9), 34-40.

Aydın, F. (2017). Willingness to communicate (WTC) among intermediate-level adult Turkish EFL learners: underlying factors. Eğitimde Nicel Araștırmalar Dergisi-Journal of Qualitative Research in Education, 5 (3), 109-137.

Bağçeci, B., \& Yaşar, M. (2007). Ortaöğretim kurumlarında İngilizce öğretimine ilişkin öğrenci görüşleri. Gaziantep University Journal of Social Sciences, 6(1), 9-16.

Bayyurt, Y. (2014). 4+ 4+ 4 Ĕ̆itim Sisteminde Erken Yaşta Yabancı Dil Eğitimi. Yabancı Dil Eğitimi Çalıştayı Bildirileri (12-13 Kasım 2012), Ankara: Hacettepe Üniversitesi Yayınları, s. 117-127.

British Council- TEPAV Proje Ekibi. (2013). Türkiye'deki Devlet Okullarmda İngilizce Dilinin Öğretimine İlişkin Ulusal İhtiyaç Analiz. Ankara: British Council.

British Council- TEPAV Proje Ekibi. (2015). Türkiye'de yükseköğretim kurumlarnndaki İngilizce eğitimi. Ankara: British Council.

Büyükkantarcıŏlu, N. (2004). A sociolinguistic analysis of the present dimensions of English as a foreign language in Turkey. International Journal of the Sociology of Language, 165, 33-58.

Cao, Y., \& Philip, J. (2006). Interactional context and willingness to communicate: a comparison of behavior in whole class, group and dyadic interaction. System, 34, 480-493.

Carless, D. (2006). Collaborative EFL teaching in primary schools. ELT Journal, 6o(4), 328-335.

Coşkun, A. (2013). Native Speakers as Teachers in Turkey: Non-native Pre-service English Teachers' Reactions to a Nation - wide Project. The Qualitative Report, 18(29), 1-21.

Creswell, J. W. (2008). Educational research planning, conducting and evaluating quantitative and qualitative research. International Pearson Merril Prentice Hall.

Çelebi, M. D. (2006). Türkiye'de anadili eğitimi ve yabancı dil öğretimi. Erciyes Üniversitesi Sosyal Bilimler Enstitüsü Dergisi, 1(21), 285-307.

Doğan, İ. (1996). Sosyoloji, kavramlar ve sorunlar. İstanbul: Sistem Yay. 
Doğançay-Aktuna, S. (1998) The Spread Of English in Turkey And Its Current Sociolinguistic Profile. Journal of Multilingual and Multicultural Development, 19(1), 24-39.

Dörnyei, Z. (2003). Questionnaires in second language research: Construction, administration, and processing. Mahwah, NJ: Lawrence Erlbaum.

EF English Proficiency Index - Turkey. (2019). Global ranking of countries and regions Erişim adresi https://www.ef.com/wwen/epi/regions/europe/turkey/

Griffee, D.T. (2012). An introduction to second language research methods: Design and data. USA: TESL-EJ Publications.

Gürsakal, N. (2009). Çlkartmsal istatistik Minitab-SPSS uygulamah. Bursa: Dora.

Gürsoy, E., Korkmaz, S. Ç., \& Damar, A. E. (2013). Foreign language teaching within 4+4+4 education system in Turkey: Language teachers' voice. Eurasian Journal of Educational Research, 13(53), 59-74.

Haznedar, B. (2010, November). Türkiye'de yabancı dil eğitimi: Reformlar, yönelimler ve öğretmenlerimiz. In International Conference on New Trends in Education and Their Implications (s.747-755), Antalya, Turkey. Erişim adresi: http://www.iconte.org/FileUpload/ks59689/File/166.pdf

Hişmanoğlu, M., \& Özüdoğru, F. (2017). An investigation of university students' willingness to communicate in English in relation to some learner variables. Karabük University Journal of Institute of Social Science , 7(2), 449-461.

Howitt, D. \& Cramer, D. (2014). Research methods in psychology (4th ed.). Harlow, England: Pearson.

Hürriyet Eğitim Eki (2014). Prof. Yasemin Bayyurt ile bir röportaj. Erişim adresi http://www.hurriyet.com.tr/gundem/2-7-yas-arasi-dil-ogrenmede-en-kazancli-donem26709553

Hymes, D. H. (1972). On communicative competence. In J. B. Pride \& J. Holmes (Eds.), Sociolinguistics: Selected readings (Part 2, pp. 269-293). Harmondsworth, England: Penguin.

İnceçay, G., \& Atay, D. (2009, May). EFL learners' interaction with native and nonnative teachers. Paper presented at The 1st International Congress of Educational Research. Çanakkale, Turkey.

İngilizce eğitime 40 bin öğretmen (2011, Mart 23). Memurlar.net Erişim adresi https://www.memurlar.net/haber/191646/ingilizce-egitime-40-bin-yabanci-ogretmen.html

Karakaş, A., Uysal, H., Bilgin, S., \& Bulut, T. (2016). Turkish EFL learners' perceptions of native English speaking teachers and non-native English-speaking teachers in higher education. NovitasROYAL (Research on Youth and Language), 10(2), 180-206.

Kırkgöz, Y. (2009). Globalization and English language policy in Turkey. Educational Policy, 23(5), 663684. http://doi.org/10.1177/0895904808316319

Koru, S., \& Akesson, J. (2011). Türkiye’nin İngilizce Açığı. Ankara: Türkiye Ekonomi Politikaları Araştırma Vakfı. 1-19, Erişim adresi: http://www.tepav.org.tr/upload/files/13297228036.Turkiye_nin_Ingilizce_Acigi.pdf

Krashen, S. (1982). Principles and practices in second language acquisition. Oxford: Pergamon.

Lin, Y. C. (2001). A study of the employment of foreign English teachers by Hsin Chu City as English teachers at elementary schools. (Unpublished masters' thesis), National Hsinchu Teachers College, Taiwan.

MEB. (2018). İngilizce Dersi Öğretim Programı (İlkokul ve Ortaokul 2, 3, 4, 5, 6, 7 ve 8. Sinfflar). Ankara: Talim ve Terbiye Kurulu http://mufredat.meb.gov.tr/Dosyalar/201812411191321\%C4\%BoNG\%C4\%BoL\%C4\%BoZCE\%20\%C3\%96\%C4\%9ERET\%C4\%BoM\%2oPROGRAMI\%2 oKlas\% 3 3 B6r\% 3 C 3 BC.pdf

Sarıhan, Z. (2001). Yabancı dille eğitime hayır. Öğretmen Dünyası Özel Eki, Tekışı Yay. 
Students' satisfaction with the 'Interactive English Language Classes' project and the effects of the project on students' willingness to communicate in classes / A. Karakaş (p. 194-213)

Schreier, M. (2012). Qualitative content analysis in practice. London, England: Sage.

Şener, S. (2014). Turkish ELT students' willingness to communicate in English. ELT Research Journal, 3(2), 91-109.

Widdowson, H. G. (1978). Teaching language as communication. Oxford, England: Oxford University Press.

Wu, K., \& Ke, C. (2009). Haunting native speakerism? Students' perceptions towards native English speaking teachers in Taiwan. English Language Teaching, 2(3), 44-52.

Yaman, İ. (2018). Türkiye'de İngilizce öğrenmek: zorluklar ve firsatlar. RumeliDE Dil ve Edebiyat Araștırmaları Dergisi, (11), 161-175.

Yıldırım, A., \& Şimşek, H., (2005). Sosyal Bilimlerde Nitel Araştırma Yöntemleri. 5. Baskı Ankara: Seçkin. 


\section{Ekler}

Ek 1: Ulusal medyada Etkileşimli İngilizce Dil Sınıfı Projesi

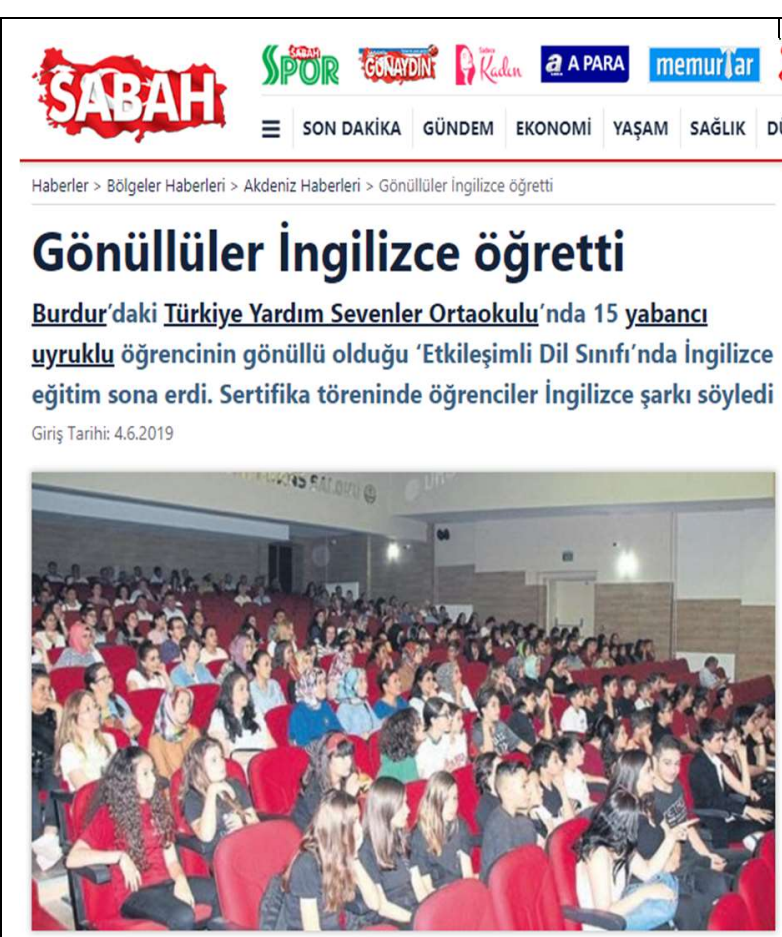

Burdur II Milli Eğitim Müdürlüğü ve Mehmet Akif Ersoy Üniversitesi Eğitim Fakültesi işbirliği ile Türkiye Yardım Sevenler Ortaokulu koordinasyonunda yürütülen 'Etkileşimli Dil Sınıfı' projesi sona erdi. Törene Ill Milli Eğitim Müdür Yardımcısı Süleyman Çakıcı, MAKÜ Eğitim Fakültesi Dekanı Prof. Dr. Sibel Karakelle, Vali Hasan Şıldak'ın eşi Fatma Nur Şıldak, öğretmenler ve öğrenciler katıldı.

\section{INGILIZCE ŞARKILAR}

Proje kapsamında 2 ilkokul, 5 ortaokul ve 1 liseden 15 Ingilizce branş öğretmeni ile MAKÜ'de eğitim gören 17 yabancı uyruklu öğrenci gönüllü çalıştı. Törende, projeye katılan okulların öğrencileri İngilizce șarkılar söylendi. Daha sonra projede gönüllü olarak görev alan Ingilizce öğretmenleri ile yabancı uyruklu öğrencilere teşekkür belgeleri verildi. Burdur Haberleri: 'Etkileşimli Dil Sınıfı' yaygınlașıyor

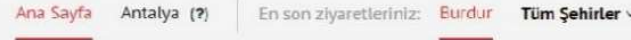

\section{'Etkileşimli Dil Sınıfı' yaygınlaşıyor}

OHA

99.11.2018-14:581 Son Gincelleme :09.11.2018 - 14:58

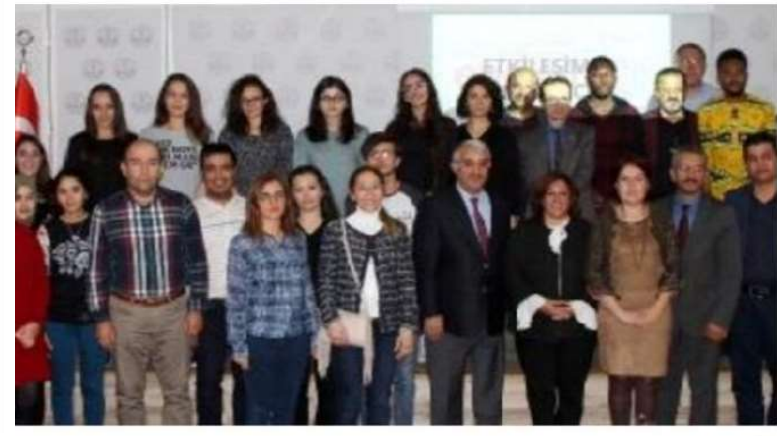

\section{f}

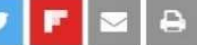

$-A+D$ Yorumyaz

Mesut MADAN/BURDUR,(DHA) - BURDUR Mehmet Akif Ersoy Universitesi ve it Milli Eăitim Müdürlüăŭ işbirliăinde geçen yıl bir okulda pilot proje olarak bașlatılan 'Etkileșimli Dil Sınıfı Projesi' yaygınlaștırılacak.

Türkive Yardımsevenler Derneği llk ve Ortaokulında geçen yıl bașlatılan 'Etkileșimli Dil Sınıfı Projesi' bu yıl Bahçelievler Şehit Sıtkı Kara I lkokulu, Altın Terim Solmaz Itkokulu, Turk Hava Kurumu Ortaokulu, ̧̧eker Imam Hatip Ortackulu, Şehit Akif Altay Ortaokulu'nda ca uygulenacak. Projenin yaygınlaștıılması için il Milli Eğitim Müdür Mahmut Bayram ile MAKU Eğitim Fakültesi Dekarı Prof.Dr. Sibel Karakelle arasında protokol imzalandı. Projcyle okullardaki İngilizce oğretmenleri vc MAKU Eğitim 「akültesinde ögrenim gören yabancı oğrerciler 8 hafta süreyle İngilizce derslerine birlikte girecek.

Proje yürütücūsï Gülizar Güzel, çeçen yıl yapılan pi iot uygulamanın başanı görüldūğùnū, bundan dolayı bu yıl daha fazla okulda yayg ıntaștınıldığını belirtti. Projenin amacının okullarda yabancı dil eğitimi verilen sınıfların 'Etkileşimli Dil Sınıfı' olarak düzenlermesi oldüuru kaydeden Güzel, "MAKU Eccitim Fakültes 'nde ögrenim gormek uzere yurt dıșından gelen oǵrencilerin yabancı dil derslerine katılarak. oğrenc lerimizle daha kalıcı ve daha yüksek düzeyde dil oğrenimini gerçekleştiri.mesi amaçlanmıștır" dedi 